\title{
The effect of audit tenure, disclosure, financial distress, and previous year's audit opinion on acceptance of going concern audit opinion
}

\author{
Annisa, NURBAITI, \\ Telkom University, Bandung, Indonesia \\ annisa.nurbaiti@yahoo.com \\ Ni Putu Ayu Intan, PERMATASARI, \\ Telkom University, Bandung, Indonesia \\ permatasaritataintan@gmail.com
}

\begin{abstract}
Going concern is about the survival of business entities, as well as a assumptions in financial statements of a business. When business entities experience conditions that are not supposed to be, the business entity is said to be in trouble. This research which aims to analyze the acceptance of going concern audit opinion using audit tenure, disclosure, financial distress, and previous year's audit opinion with case study on mining sector companies listed in Indonesia Stock Exchange in period 2013-2017.. This research used quantitative methods, and the samples were taken by using purposing sampling technique. To analyze the effect of independent variables to dependent variable was using logistic regressions analysis by using IBM Statistical Product and Service Solutions Statistics version 23. The results of this research, financial distress and the previous year audit opinion variables have a positive direction towards the acceptance of going concern audit opinion. While the audit tenure and disclosure variables have no significant influence on the acceptance of going concern audit opinion.
\end{abstract}

Keywords: Going Concern Audit Opinion; Audit Tenure; Disclosure; Financial Distress; Previous Year Audit Opinion

JEL Classification: M42

1. Introduction

Financial reports are defined as the final results of the accounting process, and are carried out by accountants for a certain period of time, and describe the results of the process of collecting and processing financial data, to facilitate the decision-making process for management. Going Concern is the survival of a business entity, as well as an estimate (assumption) on the entity's financial statements, and when a business entity experiencing a situation that is not 
supposed to be, then the business entity said to be having a problem (Petronela, 2004). This study using mining sector companies that are listed in Indonesia Stock Exchange for period 2013-2017. In predicting the survival of companies, it is not only done for public sector companies, but also for micro small and medium enterprises (MSMEs). MSMEs can also improve their performance and maintain the company continuity by using score of good corporate governance. (Novandi et al, 2018).

Public Accountant Professional Standards (SPAP) PSA 30 Section 341, 2016, going-concern audit opinion is an opinion that given by the auditor with the aim of providing certainty about the business continuity of the audited company, whether the business continuity can be maintained or not. The existence of a going concern audit opinion indicates the existence of a company risk, where the company cannot survive in normal business conditions. According to Auditing Standards (SA 570) of 2015 about 'Business Continuity', it is stated about several conditions that can lead to doubts regarding the going concern, include the position of net liabilities, negative operating cash flows, poor financial ratios, substantial operational losses, and old dividends owed.

Based on observations of the financial statements of mining sector companies, there are several companies in the mining sector that accept going concern audit opinions, one of them is Mitra Investindo Tbk (MITI), which during 2015 to 2017 MITI recorded a net operating loss and had a negative operating cash flow. Based on these conditions, the company get the going concern audit opinion in its independent auditor's report. Different with Perdana Karya Perkasa Tbk (PKPK), during the research year (2013-2017), the company had operational losses for 5 years. However, in the company's independent auditor's report, for the past 5 years the company has never received a going-concern audit opinion, even though the company has suffered an operational loss for 5 years. Based on this finding, researcher concluded that there was inconsistency in the acceptance of the goingconcern audit opinion

Audit Tenure is defined as the timeframe that described the number of years the Public Accountant Office (KAP) has a relationship with the same client or company in carrying out its audit profession. (Monica \& Rasmini, 2016) in their research found that audit tenure has a negative influence on going-concern audit opinion. However, (Pipin \& Nanda, 2018) in their research found audit tenure has no influence in accepting going-concern audit opinion.

Disclosure, is defined as a disclosure of all information about the activities that have been carried out by the company, that can influence in investment decisions. Disclosure will help readers of financial statements in seeing the 
company's financial condition in detail, (Astuti, Irtani, \& Darsono, 2012). (Saputra \& Kustina, 2018) and (Kusumayanti \& Widhiyani, 2017) in their research obtained results where disclosure has an influence on going-concern audit opinion. In contrast to (Monica \& Rasmini, 2016), who found disclosure did not affect the going concern audit opinion.

Platt and Platt (2002) in (Widhiari \& Merkusiwati, 2015) defined that financial distress is the process of decreasing the financial position of a business entity that is experienced before entity going bankrupt or liquidating. (Lucky, Siti, \& Lawe, 2018) and (Yuliani \& Erawati, 2017) found that financial distress has a negative influence on going-concern audit opinion. But it is different from (Setiadamayanthi \& Wirakusuma, 2016), where financial distress has no effect on going-concern audit opinion.

Previous Year Audit Opinion is defined as the audit opinion that the client has obtained in the previous period, or 1 year before the year of the research. (Pipin \& Nanda, 2018) and (Fahmi, 2015) found that the previous year's audit opinion had an effect on the going-concern audit opinion. In contrast to (Monica \& Rasmini, 2016), finding the audit opinion of the previous year had no effect on the going-concern audit opinion.

The objectives of this study are:

1. To find out the Audit Tenure, Disclosure, Financial Distress, Previous Year Audit Opinion, and Going Concern Audit Opinion on mining sector companies listed on the Indonesia Stock Exchange in 2013-2017.

2. To find out the effect simultaneously and partially of the Audit Tenure, Disclosure, Financial Distress, and Previous Year Audit Opinion on the acceptance of the going concern audit opinion on mining sector companies listed on the Indonesia Stock Exchange in 2013-2017.

\section{Literature Review}

\subsection{Audit Tenure and Going Concern Audit Opinion}

Audit Tenure is a time period that describes the auditor's relationship with his client, or the period of engagement between the KAP (Public Accounting Firm) and the client related to the agreed audit services. Government Regulation of the Republic of Indonesia PP No.20 of 2015 about 'Practice of Public Accountants', regulates the limitation of providing audit services for financial information, where the Public Accountants are limited for 5 years, and for KAPs are not limited in 
length. (Monica \& Rasmini, 2016) in their research stated that the caused of client and KAP engagements are long, due to the quality of audits produced by auditors and KAP when performing audits. The audit results that produced by the auditor and KAP show the actual work ability, and the client is satisfied with the results of the audit. In addition, (Maydica \& Shiddiq, 2013) also found that audit tenure has a negative effect on the acceptance of going- concern audit opinion. Auditees that have a long audit period with KAP can reduce the possibility of obtaining a going concern audit opinion. With the existence of negative influences, the longer of the audit engagement between the client and KAP, can influence the independence of the auditor and KAP in issuing their opinion, and it is feared the auditor will not give a going-concern audit opinion even though the client should receive the goingconcern audit opinion.

Audit Tenure will be determined by a ratio scale, which is to add the year which the same KAP has worked to the client. Audit engagements in the first year are given number 1 and then added 1 more for the following engagement years if the company is audited by the same KAP.

$\mathrm{H} 2$ = Audit Tenure has a negative effect on the acceptance of going-concern audit opinion.

\subsection{Disclosure and Going Concern Audit Opinion}

According to Suwardjono (2014: 580), disclosures are carried out with the aim of providing the information needed in order to achieve the functions of financial reporting, as well as to serve the stakeholders. The disclosure of company financial information, can be used as one of the factors that can trigger the auditor to release a going-concern audit opinion. The more information obtained, can facilitate investors in making investment decisions carefully and precisely. (Novandi et. Al, 2018) found that for MSMEs, they must have a financial statement to provide information about the condition of their enterprise from the point of number in monetary units. This condition was used to measure the accountability for determining the score of good corporate governance. Furthermore, for MSMEs disclosure is about the financial transparency, namely the separation between the owner's personal finances and the company's finances. These separation needs to be done in order to clarify the actual company's financial position, and the owner can take the proper decision based on the company's financial condition (Novandi et. al, 2018). (Kusumayanti \& Widhiyani, 2017) and (Saputra \& Kustina, 2018) in their research found that disclosure has a positive influence on going-concern audit opinion. With the positive influence, when a business entity discloses information 
that is more complete, it can increase opportunities for auditors to be able to obtain deeper information, and find any doubt in the continuity of the company's business, so that auditors will be easier to give their opinions.

Disclosure is measured using a disclosure level formula, and uses the Financial Services Authority Circular No.30/SEOJK.04/2016 as a basis for determining the level of disclosure of annual reports. There are 33 annual report disclosure items (Saputra \& Kustina, 2018). The formula for disclosure level is:

$$
\text { disclosure level }=\frac{\text { number of scores fulfilled }}{\text { maximum score }}
$$

H3 = Disclosure has a positive effect on the acceptance of going concern audit opinion.

\subsection{Financial Distress and Going Concern Audit Opinion}

Financial distress is defined as a situation where a company's operating cash flow is not sufficient to pay off the company's current debt, and is forced to take corrective action. (Santosa \& Wedari, 2007) in (Lucky, Siti, \& Lawe, 2018) found that financial distress is one of the indicator when business entities going bankrupt or liquidating. According to Mc. Keown (1991) in (Januarti, 2009), auditors will not release going-concern audit opinions to companies that does not experience financial distress conditions. This shows that, when a company experiences financial distress, the company has the opportunity to get a going concern audit opinion from the auditor because the company is doubtful of its survival in the short term and long term. (Widhiari \& Merkusiwati, 2015) in his research stated that companies indicated to experience financial distress if they had negative earnings per share. Earning per share (EPS) describes the business profits obtained in a certain period of time, and describes the company's performance and prospects. In addition, (Arwinda \& Merkusiwati, 2014) mention that, EPS can explain the ability of a business to be able to earn profit per share that can be shared with shareholders. If the EPS is negative, the company is indicated to experience weaken in performance that can affect the investment decisions of investors.

With the positive influence, in the releasing a going concern audit opinion, the auditor will evaluate the financial condition of the audited company. Companies that are experiencing serious financial problems that are marked by 
negative EPS records, can having the higher possibility to receive an audit opinion going concern.

Financial distress is measured using a dummy variable by looking at the company's Earning Per Share. If the company records Earning Per Share with a negative value, it will be given a value of 1 . Conversely, if Earning Per Share is positive, it will be given a value of 0 .

$\mathrm{H} 4$ = Financial Distress has a positive effect on the acceptance of going concern audit opinion.

\subsection{Previous Year's Audit Opinion and Going Concern Audit Opinion}

Previous Year Audit Opinion is defined as an audit opinion that has been obtained by the client in the previous period, or 1 year before the year of the research. The previous year's audit opinion can be used as a basis for the auditor to release the opinions of going concern, or the survival of the company in the following year, if the company's financial condition shows a financial condition that is no better than before, or there is no new management strategy to be implemented in order to improve financial condition of the company. According to the Public Accountant Professional Standards (SPAP, SA 504, 2016), when auditor finds material conditions in the previous period's financial statements, the auditor is required to give consideration to all matters in the financial statements in the previous period. (Pipin \& Nanda, 2018) and (Fahmi, 2015) found that the previous year's audit opinion had a positive effect on going-concern audit opinion. With the existence of a positive influence, the company which in the previous period has received the going concern audit opinion, can have a higher probability of receiving the going concern audit opinion in the current year.

The previous year's audit opinion was measured using a dummy variable. If the company gets a going concern audit opinion in the previous period, then it is given a value of 1 . However, if the company does not get a going concern audit opinion, then it is given a value of 0 .

$\mathrm{H} 5$ = Previous year's audit opinion has a positive effect on the acceptance of going concern audit opinion 
Figure 1. Research Framework

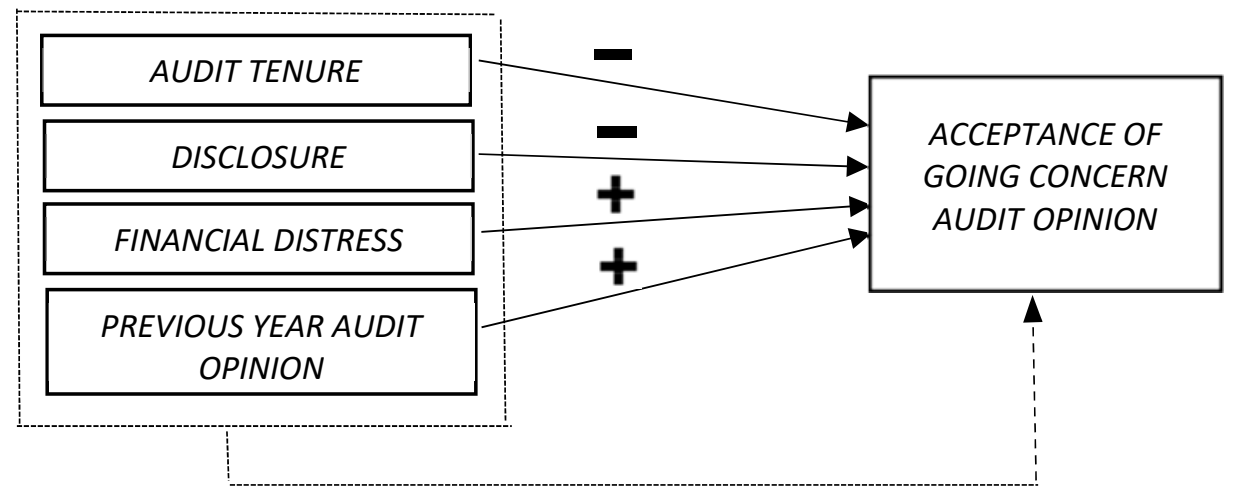

Source: Annisa, 2019

\section{Research Methods}

Quantitative methods were used in this study. Based on the type of research, this research is a descriptive verification type. The type of investigation of this study is causal, while based on the involvement of researchers is not to intervene data because researchers do not interact with data. Based on the unit of analysis are groups, with the time of implementation of panel data, namely a combination of time series and cross section.

The population that used in research are the companies in the mining sector listed on the Indonesia Stock Exchange for the period 2013-2017. The method of determining the research sample is using purposive sampling method. Purposive sampling is a sampling technique using certain considerations (Sugiyono 2013: 68). The criteria for determining the sample of this study are:

(a) Companies in the mining sector listed on the Indonesia Stock Exchange in 2018

(b) Companies that are not consistently listed on the Indonesia Stock Exchange during the period 2013-2017

(c) Companies that do not consistently publish annual reports and financial reports on the Indonesia Stock Exchange during the 2013-2017 period. 
There were 32 samples in a period of 5 years, which resulted in a total of 160 samples. This study uses a logistic regression analysis method, with the following equation:

$$
O G C=\alpha+\beta 1 A T+\beta 2 D+\beta 3 F D+\beta 4 O T S+e
$$

Information :

OGC = Going concern audit opinion (value 1 when receiving a going concern audit opinion, value 0 if receiving a non-going concern audit opinion)

$$
\begin{array}{ll}
\alpha & =\text { Constant } \\
\beta & =\text { Regression Coefficient } \\
\text { AT } & =\text { Audit Tenure } \\
\text { D } & =\text { Disclosure } \\
\text { FD } & =\text { Financial Distress } \\
\text { OTS } & =\text { Previous Year's Audit Opinion } \\
\text { e } & =\text { error }
\end{array}
$$

4. Results

4.1. Descriptive Statistical Analysis

Table 1. Descriptive Statistical

\begin{tabular}{lccccc}
\hline & $\mathrm{N}$ & Minimum & Maximum & Mean & Std. Deviation \\
\hline AT & 160 & 1 & 5 & 2.41 & 1.328 \\
D & 160 & 0.64 & 1.00 & 0.9114 & 0.07902 \\
FD & 160 & 0 & 1 & 0.34 & 0.476 \\
OTS & 160 & 0 & 1 & 0.08 & 0.274 \\
GC & 160 & 0 & 1 & 0.11 & 0.317 \\
Valid N (listwise) & 160 & & & & \\
\hline
\end{tabular}

Source: Annisa, 2019

Based on the results, it appears that the mean of audit tenure and disclosure variables is higher than the standard deviation, so it can be concluded that the sample of these variables is homogeneous or relatively the same. In addition, the mean from the financial distress, the previous year's audit opinion, 
and the going concern audit opinion are smaller than the standard deviation, so that it can be concluded that the sample of these variables is not grouped or varied.

\subsection{Logistic Regression Analysis}

4.2.1. Assessing the Feasibility of the Regression Model

Table 2. Hosmer and Lemeshow's Goodness of Fit Test

\begin{tabular}{lccc}
\hline Step & Chi-square & df & Sig. \\
\hline 1 & 4.867 & 8 & 0.772 \\
\hline \multicolumn{4}{c}{ Source: Annisa, 2019}
\end{tabular}

The table above shows the results of the feasibility testing of the regression model, and obtained the chi-square value of 4.867 with a significance level of 0.772 , where the value is greater than 0.05 . Then the hypothesis $\mathrm{HO}$ is acceptable and $\mathrm{Ha}$ is rejected. This shows if the regression model that used in this research can predict the observation value.

\subsubsection{Assessing the Fit Model}

Table 3. Overall Model Fit

\begin{tabular}{|c|c|}
\hline-2 LogL Block Number 0 & 112,547 \\
\hline-2 LogL Block Number 1 & 51,685 \\
\hline
\end{tabular}

Source: Annisa, 2019

In table 3 , the the first $-2 \operatorname{LogL}(-2 \operatorname{LogL}$ Block Number 0 ) has a value of 112,547 , and the final value of $-2 \log L(-2 \operatorname{LogL}$ Block Number 1$)$ has a value of 51,685 . Based on these results, it can be seen that there is a decrease in value at $2 \log \mathrm{L}$ of 60,862 . Therefore, the Ha hypothesis is accepted, which describes the model. Research regression is getting better or more fit with the data. 


\subsubsection{Coefficient of Determination $\left(R^{2}\right)$}

Table 4. Coefficient of Determination

\begin{tabular}{lcrr}
\hline Step & $\begin{array}{c}-2 \text { Log } \\
\text { likelihood }\end{array}$ & $\begin{array}{c}\text { Cox \& Snell } \\
\text { R Square }\end{array}$ & $\begin{array}{c}\text { Nagelkerke R } \\
\text { Square }\end{array}$ \\
\hline 1 & $5^{51.685^{a}}$ & 0.316 & 0.626 \\
\hline \multicolumn{4}{c}{ Source: Annisa, 2019}
\end{tabular}

In Table 4, we can see the results of testing the coefficient of determination that describes the ability of independent variables to influence the dependent variable. The value of Nagelkerke $R$ Square is 0.626 . So, it can be concluded that the variable audit tenure, disclosure, financial distress and previous year's audit opinion can describe the variation on acceptance of the going concern audit opinion for $62.6 \%$, and the rest by $37.4 \%$ illustrated by other factors not involved in this study.

\subsubsection{Silmutaneous Testing (Test $f$ )}

Table 5. Omnibus Test Of Model Coefficients

\begin{tabular}{ccccc}
\hline & & Chi-Square & df & Sig. \\
\hline Step 1 & Step & 60.862 & 4 & 0.000 \\
& Block & 60.862 & 4 & 0.000 \\
& Model & 60.862 & 4 & 0.000 \\
\hline
\end{tabular}

Source: Annisa, 2019

At table 5, the value of Chi-Square is 60,862 and the degree of freedom (df) is 4 , and the significance value is $0,000 \quad(1,9113 \mathrm{E}-12)$. Therefore, the hypothesis $\mathrm{HO} 1$ is rejected and $\mathrm{Ha} 1$ is accepted, because the significance value is smaller than 0.05 . This illustrates that variabel audit tenure, disclosure, financial distress and previous year's audit opinion can affect the acceptance of going concern audit opinion simultaneously. 
4.2.5. Partial Testing (Test $t)$

Tabel 6. Variables in Equation

\begin{tabular}{|c|c|c|c|c|c|c|c|}
\hline & & B & S.E. & Wald & $d f$ & Sig. & $\operatorname{Exp}(B)$ \\
\hline \multirow[t]{5}{*}{ Step $1^{a}$} & AT & 0.350 & 0.314 & 1.237 & 1 & 0.266 & 1.418 \\
\hline & $D$ & 0.980 & 5.222 & 0.035 & 1 & 0.851 & 2.666 \\
\hline & FD & 1.877 & 0.921 & 4.157 & 1 & 0.041 & 6.537 \\
\hline & OT & 5.848 & 1.227 & 22.733 & 1 & 0.000 & 346.690 \\
\hline & Cor & -5.900 & 4.983 & 1.402 & 1 & 0.236 & 0.003 \\
\hline
\end{tabular}

Source: Annisa, 2019

From the results of the partial test above, the equation of the regression model is obtained as follows:

$$
O G C=-5.900+0.350 A T+0.980 \mathrm{D}+1.877 \mathrm{FD}+5.848 \mathrm{OTS}+\mathrm{e}
$$

The explanation of the regression equation is:

1. The constant value is obtained by $-5,900$ which indicates that when the audit tenure, disclosure, financial distress, the previous year's audit opinion variables is 0 , then the value of the going concern audit opinion is $-5,900$.

2. The regression coefficient value of tenure audit is obtained by 0.350 which indicates that when the audit tenure is worth 1 and disclosure, financial distress, the previous year's audit opinion is 0 , there will be an increase in the acceptance of going concern audit opinion by 0.350 .

3. The regression coefficient value of disclosure is obtained by 0.980 , which shows that when disclosure is worth 1 and audit tenure, financial distress, the previous year's audit opinion is 0 , there will be an increase in the acceptance of going concern audit opinion by 0.980 .

4. The regression coefficient value of financial distress is obtained by 1.877 , which shows that when financial distress is worth 1 and audit tenure, disclosure, the previous year audit opinion is worth 0 , there will be an increase in the acceptance of going concern audit opinion acceptance by 1.877.

The regression coefficient of the previous year audit opinion is obtained by 5,848 , which indicates when the previous year's audit opinion was worth 1 and 
audit tenure, disclosure, and financial distress was worth 0 then, there was an increase in the acceptance of going concern audit opinion by 5,848 .

\section{Discussion and Conclusions}

\subsection{Discussion}

5.1.1. Discussion of hypothesis 2 (H2) the effect of Audit Tenure on the acceptance of going concern audit opinion

Based on the results of the test, the significance value of the partial hypothesis test is 0.266 . This illustrates that the audit tenure does not affect the acceptance of going-concern audit opinion. KAP that has a long audit range with its client, will be releasing a going concern audit opinion if there is any doubt in the continuity of the audited company, so that it can be concluded that the auditor's independence level is not affected by the length of the audit assignment. The longer the audit engagement between KAP and the company, the auditor can increase their knowledge about the condition of the company so that it makes it easier for auditors to find problems.

The results of this study support the research by (Pipin \& Nanda, 2018) and (Fahmi, 2015) which states that audit tenure does not significantly influence the acceptance of going-concern audit opinion.

5.1.2. Discussion of hypothesis $3(\mathrm{H3})$ the effect of Disclosure on the acceptance of going concern audit opinion

Based on the results of the test, the significance value of the partial hypothesis test is 0.851 . This illustrates that disclosure does not affect the acceptance of going-concern audit opinion. This is due to the fact that not all disclosure samples that fully disclose the annual report information, getting a going concern audit opinion. In addition, there are several samples that are incomplete in disclosing the annual report information, also get a going-concern audit opinion. This proves that, disclosure of company information in the annual report does not affect the auditor to release a going-concern audit opinion. In addition, disclosure items that must be submitted by the company have been regulated in the Financial Services Authority Circular No.30/SEOJK.04/2016 concerning the Form and Content of the Annual Report of Issuers or Public 
Companies. The regulation becomes a reference for companies in publishing annual reports.

The results of this study support the research by (Maydicca \& Shiddiq, 2013) and (Fahmi, 2015) which found that disclosure did not affect the acceptance of going-concern audit opinion.

5.1.3. Discussion of hypothesis 4 (H4) the effect of Financial Distress on the acceptance of going concern audit opinion

Based on the results of the test, the significance value of the partial hypothesis test is 0.041 . This illustrates that financial distress have a positive effect on the acceptance ofgoing-concern audit opinion. If the company indicated to experience financial distress, the higher the possibility of the company to accept going-concern audit opinion. Companies that tend to experience financial difficulties, are indicated by having negative earnings per share. Earning per share can describe the profit the company gets during the reporting period, and describes the company's past performance and future prospects for the company (Widhiari \& Merkusiwati, 2015).

In addition, earnings per share can also describe how much the company is able to to generate profits per share that will be shared with shareholders (Arwinda \& Merkusiwati, 2014). So, if the company has negative earnings per share, then it can indirectly illustrate that the company cannot share profits. Instead it distributes losses to shareholders. Based on the results of observations on the financial statements of the research sample, the negative value of earnings per share recorded can be caused by several factors such as declining income, increasing in cost of goods sold and other expenses, and sales loss or loss in fixed assets. If this happens continuously, investors can withdraw their capital, and the company will find it difficult to obtain funding to finance the company, so that this condition can trigger the company to experience financial distress. 
5.1.4. Discussion of hypothesis 5 (H5) the effect of Previous Year Audit Opinion on the acceptance of going concern audit opinion

Based on the results of the test, the significance value of the partial hypothesis test is 0,000 . This illustrates that the previous year's audit opinion has a positive effect on the acceptance of going-concern audit opinion. When a company receives a going-concern audit opinion in the previous period, the company must show an increase in significant financial conditions, to not getting a going-concern audit opinion again. If the financial condition of the company shows a financial condition that is no better than before or the unavailability of a strategy from management that can be implemented to improve the company's financial condition, then the possibility of receiving a going concern audit opinion will increase.

The results of this study are in accordance with the theory according to SPAP (SA 504, 2016), when auditor finds material occurrence in the previous period's financial statements, the audit of the financial statements for the following year must be reconsidering the occurrence that have a material impact. Based on the results of observations on financial statements, there are cases that auditor will giving back the going concern audit opinion, such as losses resulting in equity deficiencies, the company records current liabilities that are greater than current assets, losses and has negative operating cash flows.

The results of this study support the research by (Pipin \& Nanda, 2018), (Fahmi, 2015) and (Maydica \& Shiddiq, 2013) who found that the previous year's audit opinion had a positive effect on the acceptance of going-concern audit opinion.

\section{Conclusions}

Based on the results of simultaneous testing of significance, it can be concluded that the audit tenure, disclosure, financial distress, and previous year audit opinions have an effect simultaneously on the acceptance of the going concern audit opinion with determination coefficient by 0.62 or $62 \%$. While based on the partially testing, audit tenure and disclosure does not have a significant effect towards the acceptance of going concern audit opinion. Financial distress and previous year audit opinion has a significant effect on the positive direction towards the acceptance of going concern audit opinion on mining sector 
companies listed in Indonesia Stock Exchange in period 2013-2017.

\section{References}

[1] Arwinda, N. W., \& Merkusiwati, N. K. (2014). Effect of Corporate Governance, Liquidity, Leverage, and Company Size Mechanisms on Financial Distress. Accounting E-Journal of Udayana University 7.1, ISSN: 2302-8556, 93-106.

[2] Astuti, Irtani, R., \& Darsono. (2012). Effect of Financial and Non-Financial Factors on the Acceptance of Going Concern Audit Opinion. Diponegoro Journal of Accounting, 1- 10.

[3] Fahmi, M. N. (2015). The effect of audit tenure, previous year audit opinion, and disclosure on going concern audit opinions. Accountability, Vol. VIII No. 3, December 2015, P-ISSN: 1979858X, 162-170.

[4] Financial Services Authority Circular Letter No.30/SEOJK.04/2016 about the Form and Content of the Annual Report of Issuers or Public Companies.

[5] Indonesian Accounting Association, (2016). Professional Accountant Professional Standards. Jakarta: Salemba Empat Publisher.

[6] Januarti, I. (2009). Analysis of the Effect of Company Factors, Auditor Quality, Company Ownership on the Acceptance of Going Concern Audit Opinions (Manufacturing Companies Listed on the Indonesia Stock Exchange). Journal and Proceedings of the 12th National Symposium on Accounting (SNA 12), Palembang, November 2009.

[7] Kusumayanti, E. N., \& Widhiyani, S. N. (2017). Influence of Opinion Shopping, Disclosure and Kap Reputation in Going Concern Audit Opinions. Accounting E-Journal of Udayana University Vol. 18.3. March 2017 ISSN: 2302-8556, 2290-2317.

[8] Lucky, N., Siti, N., \& Lawe, A. (2018). Factors affecting going concern audit opinion. Sikap, Vol 2 (No. 2), 2018, p-ISSN: 2541-1691, 96-111.

[9] Maydica, A. R., \& Shiddiq, R. N. (2013). Factors affecting the admission of going concern audit opinions. Diponegoro journal of accounting Volume 2, Number 3, 2013, Page 1 ISSN (Online): 2337-3806.

[10] Monica, K., \& Rasmini, N. K. (2016). Factors Affecting Going Concern Audit Opinion. Accounting E-Journal of Udayana University Vol. 14.1 January 2016 ISSN: 2303-1018, 451-481.

[11] Munawir, S. (2015). Analysis of Financial Statements. Jakarta: Salemba Empat.

[12] Novandi, Dito R., Yuneline, Mirza H., Diryana, I. (2018). Creating MSMES governance indicators, as evaluation tools and reference in creating a good corporate governance. Journal of business and finance in emerging markets, ISSN: 2580-5576.

[13] Petronela, T. (2004). Going Concern Considerations of Companies in Providing Money Opinions. Balance Journal, 47-55.

[14] Pipin, K., \& Nanda, M. F. (2018). Going Concern Audit Opinion: Study Based on Audit Quality, Financial Conditions, Audit Tenure, Company Size, Company Growth and Previous Year Audit Opinion on Companies Experiencing Financial Distress in Manufacturing Companies. Journal of Accounting And Financial Research, 6 (1), ISSN: 2541-061X (Online), 105-122.

[15] Republic of Indonesia Government Regulation PP No.20 of 2015 about Practices of Public Accountants.

[16] Saputra, E., \& Kustina, K. T. (2018). Analysis of the Effect of Financial Distress, Debt Default, Quality of Auditor, Auditor Client Tenure, Opinion Shopping and Disclosure, on Acceptance of Going Concern Audit Opinions in Manufacturing Companies Listed in Indonesia Stock Exchange. KRISNA Journal: Collection of Accounting Research; Vol. 10, No. July 1, 2018, ISSN: 
2301-8879.

[17] Setiadamayanthi, A. N., \& Wirakusuma, M. (2016). The effect of auditors switching and financial distress on going concern audit opinions. Accounting E-Journal of Udayana University Vol. 15.3. June (2016): ISSN: 2302-8556, 1654-1681.

[18] Sugiyono. (2013). Statistics for Research. Bandung: Alfabeta.

[19] Suwardjono. (2014). Accounting Theory: Financial Reporting Engineering, Third Edition. Yogyakarta: BPFE.

[20] Widhiari, N. L., \& Merkusiwati, N. A. (2015). The Effect of Liquidity, Leverage Ratio, Operating Capacity, and Sales Growth on Financial Distress. Accounting E-Journal of Udayana University 11.2, ISSN: 2302-8556, 456- 469.

[21] Yuliani, A. N., \& Erawati, A. N. (2017). The Effect of Financial Distress, Profitability, Leverage and Liquidity on the Going Concern Audit Opinion. Accounting E-Journal of Udayana University Vol. 19.2. May (2017): ISSN: 2302-8556, 1490-1520. 